\title{
PREOPERATIVE FEMORAL VEIN VELOCITY IN MAXIMAL FLEXION IS A PREDICTOR OF DEEP VEIN THROMBOSIS IN PATIENTS UNDERGOING TOTAL HIP ARTHROPLASTY
}

\author{
Amel Hadžimehmedagić ${ }^{1}$, Bekir Rovčanin ${ }^{2}$, Haris Vranić1, Muhamed Djedović ${ }^{1}$, \\ Slavenka Štraus ${ }^{3}$ and Tarik Selimović ${ }^{2}$
}

\begin{abstract}
${ }^{1}$ Department of Vascular Surgery, Sarajevo University Clinical Centre, Sarajevo, Bosnia and Herzegovina;
${ }^{2}$ Public Health Centre of Sarajevo Canton, Sarajevo, Bosnia and Herzegovina;

${ }^{3}$ Department of Anesthesiology, Sarajevo University Clinical Centre, Sarajevo, Bosnia and Herzegovina
\end{abstract}

\begin{abstract}
SUMMARY - The aim of the study was to investigate if preoperative blood flow velocity in femoral vein in different positions of the hip during total hip arthroplasty (THA) is a predictor of postoperative deep vein thrombosis (DVT). In patients undergoing THA, blood flow velocity and diameter of proximal femoral vein on THA side were measured preoperatively in four flexion positions of the hip. After THA, patients were followed up for 42 days for DVT occurrence, and clinical features of patients with and without postoperative DVT were compared. The mean blood flow velocity in maximal flexion $\left(90^{\circ}+\right)$ preoperatively was significantly lower in patients with postoperative DVT (19/103) compared to patients without it $(8.4 \pm 2 \mathrm{~cm} / \mathrm{s} v s .10 .6 \pm 2.3 \mathrm{~cm} / \mathrm{s} ; \mathrm{p}<0.001)$. Using the receiver operating characteristic curve analysis, the cut-off value for blood flow velocity during maximal flexion was $8.24 \mathrm{~cm} / \mathrm{s}$. In addition, anesthesia duration, duration of surgical position of the patient, body mass index, amount of blood transfused after surgery, and clinical signs of DVT were markedly different between patients with and those without postoperative DVT. Blood flow velocity in femoral vein in maximal flexion of the hip $\left(90^{\circ}+\right)$ measured prior to THA is an independent predictor of postoperative DVT.
\end{abstract} flexion

Key words: Total hip arthroplasty; Deep vein thrombosis; Blood flow velocity; Femoral vein; Maximal

\section{Introduction}

The incidence of total hip arthroplasty (THA) has been increasing globally in the last 2-3 decades and it is projected to continue increasing in the future to the rate of up to $40 \%$ in $2030^{1-3}$. Following THA, venous thromboembolism (VTE) is one of the most common major complications. VTE has two manifestations, i.e. deep vein thrombosis (DVT) and pulmonary embo-

Correspondence to: Bekir Rovíanin, $M D$, Public Health Centre of Sarajevo Canton, Alajbegovića 1, 7100 Sarajevo, Bosnia and Herzegovina

E-mail: bekir_rovcanin@hotmail.com

Received October 24, 2018, accepted January 7, 2019 lism (PE). DVT in particular can be a serious complication because it can lead to fatal $\mathrm{PE}^{4}$. With the use of thromboprophylactic therapy, the incidence of symptomatic VTE is $1.4 \%-6 \%$, whereas without thromboprophylactic therapy it rises to $20 \% 0^{1,3,5}$. The incidence of asymptomatic VTE is much higher than of symptomatic VTE, ranging from $45 \%$ to $65 \%$ after arthroplasty of the hip or knee 6 . Our understanding of the pathophysiology of DVT has been greatly improved in the last three decades, but results regarding predictors of DVT are still ambiguous and confusing. Venous stasis is a well-known factor contributing to developing DVT, but it has shown limited use as a possible clinical predictor of thromboembolic events ${ }^{7-9}$. Assess- 
ment of preoperative Doppler ultrasonography vein flow velocity and its role in postoperative DVT occurrence in surgery patients had a limited use in the past. There are a small number of studies of vein flow velocity and its role in postoperative DVT. Some studies were conducted in laparoscopic, gastric bypass and inguinal hernioplasty patients, where vein flow velocity was followed up postoperatively as a predictor factor of postoperative DVT, without assessing preoperative vein flow velocity ${ }^{10-12}$. During THA, the lower limb is placed in many different positions, of which in some positions such as hyperflexion the veins can be compressed and blood flow velocity decreased, leading to vein stasis, possible thrombus formation, and consequent DVT and VTE ${ }^{13-15}$.

Given the steady increase in the incidence of THA procedures, as well as the high rate of postoperative DVT, it is necessary to find ways to improve the existing preoperative and prophylactic strategies for $\mathrm{pa}^{-}$ tients undergoing THA. Therefore, in this study, we aimed to investigate if preoperative blood flow velocity in the proximal femoral vein in different flexion positions of the hip used during THA could be used as a predictor of postoperative DVT in patients undergoing THA. For this purpose, we measured preoperative ultrasonic blood flow velocity and diameter of proximal femoral vein in different flexion positions of the hip, and evaluated it with respect to the occurrence of postoperative DVT.

\section{Patients and Methods}

This was a single-center study conducted from January 2011 to October 2013. The investigation was designed as a prospective observational clinical cohort study. The study was approved by the institutional Ethics Committee and an informed consent was obtained from all patients. Patients admitted for THA were included in the study. Exclusion criteria were as follows: history of DVT, thrombophlebitis, previous hip operations, congestive heart failure, chronic kidney disease, morbid obesity (body mass index, BMI $\geq 32.0$ ), cerebrovascular disease, coagulopathy, malignant disease, liver disease, chronic arterial insufficiency (stage $\geq \mathrm{II}$ ), and restricted hip mobility (impossible to flex hip more than $90^{\circ}$ ).

Preoperatively, we performed Doppler ultrasonography examination in B-mode and color Doppler ul- trasonography in four positions: full extension $\left(0^{\circ}\right)$,

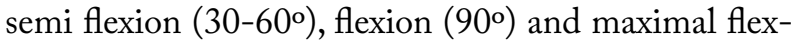
ion $\left(90^{\circ}+\right)$ of the hip at the planned surgical site and in supine position. Subsequently, we measured maximal blood flow velocity in femoral vein in maximal proximal position, distally of the confluence of profound femoral vein, as it was possible due to anatomic characteristics of the patient, and perpendicular angle of the sound to the vein, as well as femoral vein diameter. In addition, all lower limb veins at the surgical site were evaluated for thrombosis. Each patient was placed in a simulated position and on the side of the planned hip surgery after 5-minute ultrasonography using the GE Volusion 730 pro ultrasound model with 7.5-10 $\mathrm{MHz}$ linear probe had been performed. The hip was fixed in a simulated position during ultrasound examination by assistance of a second examiner, holding the heel and the knee. All variables were measured by the same vascular surgeon three times and the mean value was obtained.

During THA, we measured the duration of anesthesia (in minutes), from the moment the patients lost their consciousness until the moment they were able to respond to questions. Total duration of all forced surgery positions (in minutes) and the amount of blood administered after surgery were also measured. All surgeries were performed using general anesthesia. From 10-12 hours after THA and until discharge, all patients were early mobilized and received pharmacological thromboprophylaxis with low molecular weight heparin (LMWH, $40 \mathrm{mg}$ subcutaneously). After discharge, all patients continued receiving $\mathrm{LMWH}$ until day 42 , and after that continued taking acetylsalicylic acid $100 \mathrm{mg}$ daily for one year. On postoperative day 1 , patients started with their rehabilitation program and were mobilized in their room.

Their BMI was measured at admission to our department. Laboratory tests of international normalized ratio (INR), activated partial thromboplastin time (APTT), blood cell count and hemoglobin level were collected both preoperatively, 7 days prior to THA, and postoperatively on days $1,3,7,12,21$ and 42 . At the same postoperative visits, ultrasound status of lower limb veins and signs of DVT, as well as clinical signs of DVT (edema, pain, palpable cord, venous dilatation, warmth) were also assessed on the same side of THA, using the same methods as those employed preoperatively. All amounts of blood transfusion administered 
Table 1. Comparison of demographic and clinical characteristics

\begin{tabular}{|l|l|l|l|}
\hline & DVT & non-DVT & $\mathrm{p}$ \\
\hline $\mathrm{n}$ & 19 & 84 & \\
Age, yrs, mean (SD) & $58.8(14.1)$ & $55.77(14.1)$ & 0.407 \\
Men, $\mathrm{n}$ & 4 & 22 & 0.642 \\
Clinical signs of DVT, $\mathrm{n}$ & 15 & 26 & $<0.001$ \\
Anesthesia duration, min, mean (SD) & $197.6(52.1)$ & $154.3(36.8)$ & $<0.001$ \\
Position duration, min, mean (SD) & $99.7(41.7)$ & $66.3(24.3)$ & $<0.001$ \\
BMI, kg/m ${ }^{2}$, mean (SD) & $27.6(2.4)$ & $26.3(2.2)$ & 0.034 \\
RBC, $x 10^{12} / \mathrm{L}$, mean (SD) & $4.6(0.4)$ & $4.7(0.4)$ & 0.5 \\
WBC, $x 10^{9} / \mathrm{L}$, mean (SD) & $6.9(1.4)$ & $7.3(1.5)$ & 0.364 \\
PBC, $x 10^{9} / \mathrm{L}$, mean (SD) & $252.8(31.1)$ & $258.5(58.8)$ & 0.684 \\
INR, mean (SD) & $0.96(0.13)$ & $0.92(0.14)$ & 0.31 \\
APTT, mean (SD) & $28.6(2.9)$ & $28.9(2.8)$ & 0.668 \\
Transfusion D0, mL, mean (n, SD) & $597.4(18,439.5)$ & $623.2(81,205.3)$ & 0.626 \\
Transfusion D0+, mL, mean (n, SD) & $220.8(15,304.4)$ & $160.1(23,297.9)$ & $<0.001$ \\
\hline
\end{tabular}

$\mathrm{SD}=$ standard deviation; $\mathrm{DVT}=$ deep vein thrombosis; $\mathrm{BMI}=$ body mass index $\mathrm{RBC}=$ red blood cell count; $\mathrm{WBC}=$ white blood cell count; $\mathrm{PBC}=$ platelet blood count; INR = international normalized ratio; APTT = activated partial thromboplastin time; $\mathrm{D} 0=$ intraoperative; $\mathrm{D} 0+=$ postoperative

were recorded. D-dimer was postoperatively collected only in patients who had clinical or ultrasonic signs of DVT, and were clinically suspected of or had a confirmed diagnosis of $\mathrm{PE}$. All patients suspected of $\mathrm{PE}$ underwent computer tomography $(\mathrm{CT})$ angiography of the chest.

For statistical analysis, patients were divided into DVT and non-DVT groups based on the occurrence of DVT confirmed by Doppler ultrasound.

\section{Statistical analysis}

Statistical analyses were performed by use of MedCalc for Windows, version 12.6.1.0. (MedCalc Software, Mariakerke, Belgium). Continuous variables were expressed as mean \pm standard deviation $(\mathrm{SD})$. We compared demographic and baseline clinical characteristics between DVT and non-DVT groups using Student's t-test for continuous variables. The $\chi^{2}$-test was used to compare categorical variables. Blood flow velocity and proximal femoral vein diameter on the side of hip surgery, anesthesia duration and all forced surgical position duration as predictive tests were assessed by the receiver operating characteristic (ROC) curve analysis. We divided patients into two groups with values equal or lower than cut-off value and with values higher than cut-off value, and calculated relative risk (RR) of developing DVT. The sensitivity and specificity of clinical signs for diagnosing DVT were calculated. To identify independent predictor of postoperative DVT, an appropriate predictor model was established by logistic regression analysis. The probability value of $<0.05$ was considered statistically significant.

\section{Results}

During the study period from January 2011 to October 2013, we enrolled 139 patients, of which 36 were excluded. Thus, a total of 103 patients, 77 women and 26 men, were included in the study. Their mean age was $56.33 \pm 14.04$ years. DVT was detected in 19 (18.4\%) patients (DVT group) using color Doppler. The mean time of DVT detection was $19 \pm 7.8$ postoperative days. The number and localization of detected DVT were as follows: 6 in soleal vein, 5 in tibial veins, 5 in popliteal vein, and 6 in femoral vein. In three patients, DVT was detected in more than one vein. In 84 (81\%) patients (non-DVT group), DVT was not detected during 42 days of postoperative follow up.

Demographic and clinical characteristics of patients divided into two groups based on the occurrence of postoperative DVT are shown in Table 1. Fifteen 
Table 2. Flow velocity and vein diameter

\begin{tabular}{|l|l|l|l|}
\hline & DVT & non-DVT & $\mathrm{p}$ \\
\hline Flow 0 $0^{\text {oa }}, \mathrm{cm} / \mathrm{s}$, mean $(\mathrm{SD})$ & $18.57(3.98)$ & $19.29(3.82)$ & 0.462 \\
Diameter $0^{\circ}, \mathrm{mm}$, mean (SD) & $9.36(0.70)$ & $9.47(0.90)$ & 0.592 \\
Flow 30-60, $\mathrm{cm} / \mathrm{s}$, mean (SD) & $18.68(2.42)$ & $20.24(3.60)$ & 0.072 \\
Diameter 30-60, $\mathrm{mm}$, mean (SD) & $9.22(1)$ & $9.11(0.75)$ & 0.604 \\
Flow $90^{\circ}, \mathrm{cm} / \mathrm{s}$, mean (SD) & $9.97(0.82)$ & $9.95(0.84)$ & 0.066 \\
Diameter $90^{\circ}, \mathrm{mm}$, mean (SD) & $13(1.80)$ & $14.1(2.40)$ & 0.92 \\
Flow $90^{\circ}+, \mathrm{cm} / \mathrm{s}$, mean (SD) & $8.4(2)$ & $10.6(2.30)$ & $<0.001$ \\
Diameter $90^{\circ}, \mathrm{mm}$, mean $(\mathrm{SD})$ & $10.4(1)$ & $10.4(0.96)$ & 0.992 \\
\hline
\end{tabular}

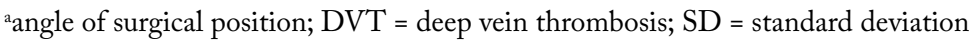

(78.9\%) patients in DVT group and 26 (30.9\%) patients in non-DVT group presented with clinical signs, at least one sign, of DVT. The sensitivity and specificity of any of the clinical signs of DVT was $78.95 \%$ and $69.05 \%$, respectively. Anesthesia duration, duration of all forced surgical positions, BMI, amount of blood administered after surgery, and any of the clinical signs of DVT were markedly different between DVT and non-DVT groups, whereas other characteristics did not differ between the groups (Table 1). In maximal flexion $\left(90^{\circ}+\right)$, blood flow velocity was significantly lower in DVT group as compared with non-DVT group $(8.4 \pm 2 \mathrm{~cm} / \mathrm{s}$ vs. $10.6 \pm 2.3 \mathrm{~cm} / \mathrm{s} ; \mathrm{p} \leq 0.001)$. In other positions, there was no significant difference between the groups (Table 2). Postoperative non-fatal $\mathrm{PE}$ occurred in eight (7.78\%) patients, including one (5.26\%) patient in DVT group and seven (8.33\%) patients in non-DVT group ( $\mathrm{p}=0.65)$.

Logistic regression analysis showed blood flow velocity in proximal femoral vein in maximal flexion to be an independent predictor of DVT (odds ratio (OR) -0.6066 ; $95 \%$ confidence interval (95\% CI) 0.439 $0.8381 ; \mathrm{p}=0.0024)$. ROC analysis indicated the cut-off value of blood flow velocity in proximal femoral vein in maximal flexion to be $8.24 \mathrm{~cm} / \mathrm{s}$, with sensitivity of $63.2 \%$ and specificity of $88.1 \%$ (Table 3, Fig. 1 ).

Blood flow velocity value equal or less than cut-off value was recorded in $63.2 \%$ of DVT patients and $11.9 \%$ of non-DVT patients. The RR of developing DVT depending on the cut-off value of blood flow velocity in maximal flexion was $5.3(\mathrm{p}<0.001)$.

In addition, ROC analysis indicated the cut-off value of anesthesia duration to be $195 \mathrm{~min}$, for all forced surgical position duration $80 \mathrm{~min}$, and diameter of proximal femoral vein in maximal flexion $10.88 \mathrm{~mm}$ (Table 3, Fig. 1). The RR of developing DVT depending on the cut-off value of anesthesia duration was 4.8 $(p<0.001)$, of all forced surgical position duration 3.4 $(p<0.001)$, and of diameter of proximal femoral vein in maximal flexion $1.48(\mathrm{p}=0.23)$.

\section{Discussion}

To our knowledge, this is the first study of this kind in patients undergoing THA. With regard to postoperative DVT occurrence, we assessed preoperative hemodynamic features of proximal femoral vein in different flexion positions of the hip during THA. This study showed preoperative blood flow velocity in proximal femoral vein at the surgical side in maximal flexion $\left(90^{\circ}\right)$ of the hip to be an independent predictor of postoperative DVT in patients undergoing THA. The cut-off value of blood flow velocity for the increased risk of DVT was $8.24 \mathrm{~cm} / \mathrm{s}$.

Venous stasis is a well-known part of Virchow triad, contributing to $\mathrm{DVT}^{7}$. However, clinical assessment of preoperative vein flow as a predictor of possible postoperative DVT was not used in practice. A small number of studies were conducted with ultrasonographic assessment of vein blood flow, with small groups of patients and limited supporting evidence 9 . In this study we demonstrated that femoral vein flow velocity in maximal flexion of the hip was slower in DVT group than in non-DVT group $(8.4 \mathrm{~cm} / \mathrm{s}$ vs. 10.6 $\mathrm{cm} / \mathrm{s} ; \mathrm{p}<0.001)$.

One of the factors that contribute to femoral vein stasis is position of the lower limb during THA. Depending on the surgical approach for THA, the lower 
Table 3. Results of ROC analysis in detection of DVT

\begin{tabular}{|l|l|l|l|l|l|}
\hline Variable & Cut-off & ACU & Sensitivity (\%) & Specificity $(\%)$ & $\mathrm{p}$ \\
\hline Blood flow velocity $90^{\circ}+(\mathrm{cm} / \mathrm{s})$ & $\leq 8.24$ & 0.77 & 63.2 & 88.1 & $<0.001$ \\
Anesthesia duration $(\mathrm{min})$ & $>195$ & 0.75 & 68.4 & 85.7 & $<0.001$ \\
Position duration $(\mathrm{min})$ & $>80$ & 0.72 & 68.4 & 79.8 & 0.005 \\
Diameter of vein $90^{\circ}(\mathrm{mm})$ & $>10.88$ & 0.52 & 42.1 & 71.4 & 0.764 \\
\hline
\end{tabular}

ROC $=$ receiver operating characteristic curve; DVT = deep vein thrombosis; ACU = area under the curve; ACU 1 value represents perfect test and area of 0.5 worthless test
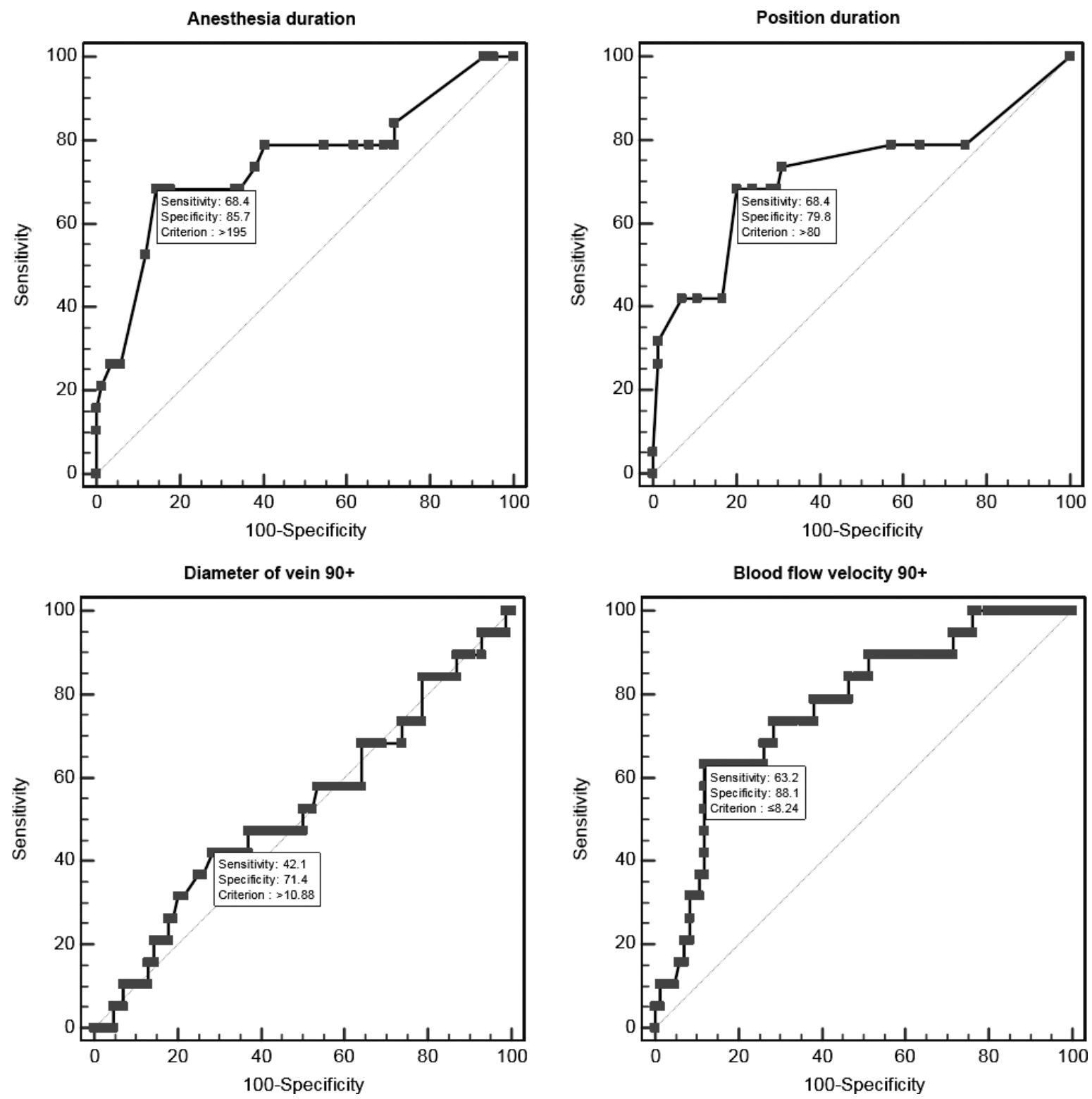

Fig. 1. Receiver operating characteristic curve: ability of anesthesia (upper right panel) and all forced surgical position duration (upper left panel); diameter (lower right panel) and blood flow velocity of proximal femoral vein in maximal flexion (lower left panel) to predict deep vein thrombosis during 42-day follow up. 
limb is placed in many positions during THA, from hyperextension to maximal flexion, leading to decrease in blood flow velocity in the femoral vein ${ }^{16}$. Studies in cadavers showed that in flexion and adduction position of the lower limb during THA, femoral vein is occluded $^{13,16}$.In a study of laparoscopic and open gastric bypass surgery, it was also shown that surgical positions of the patient could lead to vein stasis ${ }^{11}$. In 12 healthy men aged $20-50$ years who were positioned in colorectal surgery positions with $0^{\circ}, 30^{\circ}, 60^{\circ}, 90^{\circ}$ of hip flexion and abduction, the diameter of proximal femoral vein was shown to become smaller as the hip flexion advanced, leading to increase in femoral vein flow velocity ${ }^{17}$. These findings partially disagree with our results because our data demonstrated that the diameter of femoral vein was decreasing and flow velocity getting faster as the hip was more flexed at $30-60^{\circ}$ position. However, in $90^{\circ}$ position the vein diameter is larger and the velocity is slower than in the $30-60^{\circ}$ position. This could be explained by flexion position only without abduction and the influence of hydrostatic pressure in $90^{\circ}$ position on the common femoral vein $(\mathrm{CFV})$. As the hip gets hyperflexed at $90^{\circ}+$, the influence of hydrostatic pressure on femoral vein compression is smaller, which leads to smaller femoral vein diameter. When it comes to blood flow velocity, it decreased in DVT group and increased in non-DVT group, possibly due to more CFV occlusion in DVT group (Table 2).

Diagnosing DVT can be a challenging task. It can present as either symptomatic or asymptomatic form. The incidence of asymptomatic DVT after THA is estimated to be $45 \%-65 \%$, i.e. higher than the symptomatic form; thus, it is the greatest challenge to identify DVT in an asymptomatic patient in due time for diagnostic testing to prevent possible $\mathrm{PE}^{6}$. However, clinical signs are not sufficient for DVT detection and color Doppler ultrasonography is widely used by clinicians in spite of documented limitations for DVT detection $^{18}$. It should be performed in every patient with possible or suspected DVT. The sensitivity and specificity of color Doppler detection of DVT is $91 \%-100 \%$ and $95 \%-99 \%$, respectively ${ }^{18,19}$. In our study, $15 \mathrm{pa}^{-}$ tients in DVT group presented with at least one clinical sign of DVT, with sensitivity of $78.95 \%$ and specificity of $69.05 \%$ for clinical signs of DVT, confirmed on color Doppler ultrasonography.

In addition to difference in blood flow velocity in maximal flexion, patients with and without postopera- tive DVT also differ in the amount of transfused blood. Interestingly, our data suggest that the amount of blood transfused after THA was significantly higher in DVT as compared with non-DVT group (220.8 \pm 304.4 vs. $160.1 \pm 297.9 \mathrm{~mL} ; \mathrm{p}<0.001)$. In line with our results, Gray and Mackie $^{20}$ report that significantly more blood was transfused to patients with DVT compared to patients without DVT after THA. In addition, in a more recent study that included 21,943 patients undergoing colorectal resection, increased blood transfusion was associated with the occurrence of $\mathrm{VTE}^{21}$. These findings are expected because it is known that, in a surgically damaged tissue, blood transfusion can even more activate thrombus formation than endothelial damage only, and lead to $\mathrm{DVT}^{21}$. In practice, this is of relevance because it is estimated that $21 \%-70 \%$ of total knee replacement and THA patients undergo transfusion ${ }^{22}$. In addition, Joy and Bennet ${ }^{23}$ suggest that only $23 \%$ of patients receive appropriate blood transfusion after primary THA.

When it comes to the incidence of $\mathrm{PE}$, there was no significant difference between DVT and non-DVT groups in our study. Some studies have shown that development of DVT and PE after orthopedic procedures is mutually independent ${ }^{24}$. Finding the source of acute PE can be challenging; less than $30 \%$ DVT is found in acute $\mathrm{PE}^{18}$.

Our study also demonstrated that both the duration of anesthesia and duration of all forced surgical positions were significantly longer in patients with postoperative DVT compared to non-DVT group (197.6 \pm 52.1 vs. $154.3 \pm 36.8 \mathrm{~min} ; \mathrm{p}<0.001$ and $99.7 \pm$ 41.7 vs. $66.3 \pm 24.3 \mathrm{~min} ; \mathrm{p}<0.001$, respectively) (Table 3, Fig. 1). This is in line with the study that included 86,571 patients that underwent orthopedic surgeries, and showed the duration of surgery, including anesthesia duration to be an independent risk factor for the development of $\mathrm{DVT}^{25}$. Surgical teams need to pay due attention to surgical position and anesthesia duration during THA. The surgery must be well planned to avoid prolonging of anesthesia and surgery time to reduce the risk of postoperative DVT.

There are many patient-specific characteristics that can contribute to DVT after THA. A meta-analysis of ten risk factors for VTE after THA has shown that the history of VTE carries the highest risk of DVT after THA, and other factors are varicose veins, chron- 
ic heart failure, black race, BMI over 30, malignancy, hypertension, age over 80 , diabetes mellitus and female gender ${ }^{26}$. Obesity has been found to decrease antithrombin III levels and fibrinolytic activity and increase prothrombotic factors ${ }^{26}$. Our study also confirmed that BMI was higher in patients with postoperative DVT.

\section{Limitations}

The major limitation of this study was small sample size because it was a single center study with patients from a small geographic area and because many patients were not eligible for the study due to the strict exclusion criteria. Another limitation was that during preoperative ultrasonography, femoral vein blood velocity measurement was performed only in the leg on the THA side; differences in blood flow between legs can exist, and pulmonary thromboembolism can occur from the other side. In addition, our postoperative follow up was only 42 days. D-dimer was measured only in patients with symptomatic or ultrasound-confirmed DVT or pulmonary thromboembolism. Asymptomatic pulmonary thromboembolism was not determined; CT angiography was not performed in all patients. Varicose veins, one of the important risk factors for DVT, were not considered in our study.

\section{Conclusion}

In conclusion, preoperative blood flow velocity in femoral vein in maximal flexion of the hip $\left(90^{\circ}\right)$ on the THA side is a predictor of postoperative DVT. Our results suggest that patients with vein blood flow velocity in maximal flexion of the hip of less than 8.24 $\mathrm{cm} / \mathrm{s}$ are at a higher risk of postoperative DVT. To prevent DVT and its potential fatal complications, these patients require intensive postoperative care. THA should be performed within $80 \mathrm{~min}$, and anesthesia should be shorter than $195 \mathrm{~min}$ to avoid postoperative DVT risk. However, more clinical studies are required to completely understand the pathophysiology of slow vein blood flow and DVT occurrence depending on the hip position.

\section{Acknowledgments}

We are thankful to our Department staff for helping us in this study. We also thank Assoc. Prof. Aida Kulo-Ćesić, $\mathrm{MD}, \mathrm{PhD}$, for valuable suggestions in preparing this manuscript. For technical support, we are thankful to Jasmina Suko and Meliha Hadžimehmedagić.

\section{References}

1. Pedersen AB, Sorensen HT, Mehnert F, Overgaard S, Johnsen SP. Risk factors for venous thromboembolism in patients undergoing total hip replacement and receiving routine thromboprophylaxis. J Bone Joint Surg Am. 2010;92(12):2156-64, https://doi.org/10.2106/JBJS.I.00882.

2. Singh JA. Epidemiology of knee and hip arthroplasty: a systematic review. Open Orthop J. 2011;5:80-5, https://doi.org/1 0.2174/1874325001105010080.

3. Glassou EN, Pedersen AB, Hansen TB. Is decreasing mortality in total hip and knee arthroplasty patients dependent on patients' comorbidity? Acta Orthop. 2017;88(3):288-93, https:// doi.org/10.1080/17453674.2017.1279496.

4. Marušić S, Knežević A, Bačić Vrca V, et al. Implementation of venous thromboembolism prophylaxis guidelines in clinical practice: a retrospective study in two Croatian hospitals. Acta Clin Croat. 2017;56(4):657-62, https://doi.org/10.20471/ acc.2017.56.04.12

5. Abe K, Yuda S, Yasui K, Okubo A, Kobayashi C, Muranaka A, et al. Soleal vein dilatation assessed by ultrasonography is an independent predictor for deep vein thrombosis after major orthopedic surgery. J Cardiol. 2017;69(5):756-62, https://doi. org/10.1016/j.jjcc.2016.07.004.

6. White RH, Henderson MC. Risk factors for venous thromboembolism after total hip and knee replacement surgery. Curr Opin Pulm Med. 2002;8(5):365-71, https://doi. org/10.1097/00063198-200209000-00004.

7. Thomas DP. Venous thrombogenesis. Annu Rev Med. 1985;36:39-50, https://doi.org/10.1146/annurev. me.36.020185.000351.

8. Sasaki K, Miura H, Takasugi S, Jingush S, Suenaga E, Iwamoto Y. Venous hemodynamic alterations in lower limbs undergoing total joint arthroplasty. Am J Orthop. 2009;38(8):E137-40.

9. Jensen CT, Chahin A, Amin VD, Khalaf AM, Elsayes KM, Wagner-Bartak N, et al. Qualitative slow blood flow in lower extremity deep veins on Doppler sonography: quantitative assessment and preliminary evaluation of correlation with subsequent deep venous thrombosis development in a tertiary care oncology center. J Ultrasound Med. 2017;36(9):1867-74, https://doi.org/10.1002/jum.14220.

10. Morrison CA, Schreiber MA, Olsen SB, Hetz SP, Acosta MM. Femoral venous flow dynamics during intraperitoneal and preperitoneal laparoscopic insufflation. Surg Endosc. 1998;12:1213-6, https://doi.org/10.1007/s004649900823.

11. Nguyen NT, Cronan M, Braley S, Rivers R, Wolfe BM. Duplex ultrasound assessment of femoral venous flow during laparoscopic and open gastric bypass. Surg Endosc. 2003;17(2):28590, https://doi.org/10.1007/s00464-002-8812-z. 
12. Lozano FS, Sánchez-Fernández J, González-Porras JR, García-Alovio J, Santos JA, Mateos R, et al. Slow femoral venous flow and venous thromboembolism following inguinal hernioplasty in patients without or with low molecular weight heparin prophylaxis. Hernia. 2015;19:901-8, https://doi. org/10.1007/s10029-015-1353-x.

13. Heller KD, Prescher A, Zilkens KW, Forst R. Anatomic study of femoral vein occlusion during simulated hip arthroplasty. Surg Radiol Anat. 1997;19(3):133-7, https://doi.org/10.1007/ BF01627960.

14. Levine A, Huber J, Huber D. Changes in popliteal vein diameter and flow velocity with knee flexion and hyperextension. Phlebology. 2011;26(7):307-10, https://doi.org/10.1258/phleb.2010.010035.

15. Huber D, Huber J, Deyoung E. The association between popliteal vein compression and deep venous thrombosis: results of a pilot study. Phlebology. 2013;28(6):305-7, https://doi. org/10.1258/phleb.2012.011142.

16. Petis S, Howard JL, Lanting BL, Vasarhelyi EM. Surgical approach in primary total hip arthroplasty: anatomy, technique and clinical outcomes. Can J Surg. 2015;58(2):128-39, https:// doi.org/10.1503/cjs.007214.

17. Pannucci CJ, Henke PK, Cederna PS, Strachn SM, Brown SL, Moote MJ, et al. The effect of increased hip flexion using stirrups on lower-extremity venous flow: a prospective observational study. Am J Surg. 2011;202(4):427-32. https://doi. org/10.1016/j.amjsurg.2011.04.002

18. Alfonso DT, Toussaint RJ, Alfonso BD, Strauss EJ, Steiger DT, Di Cesare PE. Nonsurgical complications after total hip and knee arthroplasty. Am J Orthop. 2006;35(11):503-10.

19. Motohashi M, Adachi A, Takigami K, Yasuda K, Inoue M, Sasaki $\mathrm{S}$, et al. Deep vein thrombosis in orthopedic surgery of the lower extremities. Ann Vasc Dis. 2012;5(3):328-33, https://doi. org/10.3400/avd.oa.12.00049.

20. Gray DH, Mackie CE. The effect of blood transfusion on the incidence of deep vein thrombosis. Aust N Z J Surg. 1983;53(5):439-43,https://doi.org/10.1111/j.1445-2197.1983. tb02481.x.

21. Xenos ES, Vargas HD, Davenport DL. Association of blood transfusion and venous thromboembolism after colorectal cancer resection. Thromb Res. 2012;129(5):568-72, https://doi. org/10.1016/j.thromres.2011.07.047.

22. Carling MS, Jeppsson A, Eriksson BI, Brisby H. Transfusions and blood loss in total hip and knee arthroplasty: a prospective observational study. J Orthop Surg Res. 2015;10:48.

23. Joy PJ, Bennet SJ. The appropriateness of blood transfusion following primary total hip replacement. Ann R Coll Surg Engl. 2012;94(3):201-3, https://doi.org/10.1186/s13018-015-01886.

24. Song K, Yao Y, Rong Z, Shen Y, Zheng M, Jiang Q. The preoperative incidence of deep vein thrombosis (DVT) and its correlation with postoperative DVT in patients undergoing elective surgery for femoral neck fractures. Arch Orthop Trauma Surg. 2016;136(10):1459-64, https://doi.org/10.1007/ s00402-016-2535-4.

25. Kim JY, Khavanin N, Rambachan A, McCarthy RJ, Mlodinow AS, De Oliveria GS Jr, et al. Surgical duration and risk of venous thromboembolism. JAMA Surg. 2015;150(2):110-7, https://doi.org/10.1001/jamasurg.2014.1841.

26. Zhang J, Chen Z, Zheng J, Breusch SJ, Tian J. Risk factors for venous thromboembolism after total hip and total knee arthroplasty: a meta-analysis. Arch Orthop Trauma Surg. 2015;135(6):759-72, https://doi.org/10.1007/s00402-0152208-8.

Sažetak

\section{PRIJEOPERACIJSKA BRZINA PROTOKA FEMORALNE VENE U MAKSIMALNOJ FLEKSIJI JE PREDIKTOR ZA DUBOKU VENSKU TROMBOZU U BOLESNIKA PODVRGNUTIH TOTALNOJ ARTROPLASTICI KUKA}

\section{A. Hadžimehmedagić, B. Rovčanin, H. Vranić, M. Djedović, S. Štraus i T. Selimović}

Cilj ove studije bio je istražiti je li prijeoperacijska brzina protoka krvi u femoralnoj veni u različitim položajima kuka tijekom potpune artroplastike kuka (total hip arthroplasty, THA) prediktor poslijeoperacijske duboke venske tromboze (DVT). U bolesnika koji su podvrgnuti THA brzina protoka krvi i promjer proksimalne femoralne vene na strani THA bili su prijeoperacijski izmjereni u četiri položaja kuka. Nakon THA bolesnici su praćeni 42 dana radi provjere nastanka DVT i uspoređeni su klinički podaci bolesnika s poslijeoperacijskom DVT i onih bez DVT. Srednja brzina protoka krvi u maksimalnoj fleksiji kuka $\left(90^{\circ}+\right)$ prijeoperacijski je bila znatno niža u bolesnika s poslijeoperacijskom DVT $(19 / 103)$ u usporedbi $\mathrm{s}$ bolesnicima bez DVT $(8,4 \pm 2 \mathrm{~cm} / \mathrm{s}$ prema $10,6 \pm 2,3 \mathrm{~cm} / \mathrm{s} ; \mathrm{p}<0,001)$. Analizom ROC (receiver operating characteristic curve) dobivena je granična vrijednost brzine protoka krvi tijekom maksimalne fleksije od $8,24 \mathrm{~cm} / \mathrm{s}$. Uz to, trajanje anestezije, trajanje kirurškog položaja bolesnika, indeks tjelesne mase, količina transfundirane krvi nakon operacije i klinički znakovi DVT bili su značajno različiti između bolesnika s poslijeoperacijskom DVT i bolesnika bez DVT. Brzina protoka krvi u femoralnoj veni u maksimalnoj fleksiji kuka $\left(90^{\circ}+\right)$ izmjerena prije THA je nezavisni prediktor za poslijeoperacijsku DVT.

Ključne riječi: Artroplastika kuka; Duboka venska tromboza; Brzina protoka krvi; Femoralna vena; Maksimalna fleksija 